Jurnal Hutan dan Masyarakat. Vol. 10(2): 239-245, Desember 2018

Diserahkan: 2018-08-11; Diterima: 2018-12-27

ISSN: 1907-5316 ISSN ONLINE: 2613-9979

\title{
Nilai Manfaat Ekonomi Hutan Kota Universitas Hasanuddin Makassar
}

\author{
Muthmainnah¹ Muhammad Tahnur ${ }^{1}$ \\ 1Program Studi Kehutanan, Universitas Muhammadiyah Makassar \\ *Email : muthmainnah.zainuddin@unismuh.ac.id
}

\begin{abstract}
This research aims to (1) identify the current indirect economic benefit resources of Hasanuddin University's urban forest (2) find out the indirect economic benefit value of Hasanuddin University's urban forest. This research has been implemented for 6 months during March to August 2018. The economic benefit value consists of wood value, coolness value and water absorption value. Method used to obtain the wood value is calculated based on market price approach, the coolness value of the urban forest is based on the market value of substitute goods while the water absorption value is calculated based on the trees' ability in absorbing water. The research result shows that the urban forest of Hasanuddin University has a very large and high benefit value. Some indirect economic benefit values contained in the urban forest are of the wood value, coolness benefit value and water absorption benefit value. The wood value of Hasanuddin University's urban forest is Rp. 46.586.400/year The coolness economic value is calculated from the total cost of procuring Air Conditioner (AC) and the maintenance cost. The coolness value of Hasanuddin University's urban forest is Rp. 3.6828.000.000. The economic value of water absorption of Hasanuddin University's urban forest is calculated based on the trees' ability to hold water. The economic value of water absorption of Hasanuddin University's urban forest is Rp. 384.189,12/days so that the water absorption of Hasanuddin University's urban forest is Rp. 140.229.028,8/year.
\end{abstract}

Keywords: Coolness value, economic value, wood value, urban forest, water absorption value DOI: http://dx.doi.org/10.24259/ihm.v10i2.4874

\section{PENDAHULUAN}

Indonesia adalah negara beriklim tropis yang berbentuk kepulauan. Kondisi ini menjadikan Indonesia sebagai negara yang memiliki banyak potensi sumber daya alam. Sumber daya alam biotik maupun sumber daya alam abiotik ini memberikan banyak manfaat bagi masyarakat dan negara. Diantara potensi sumber daya alam Indonesia yang dapat diperbaharui maupun yang tak terbaharukan adalah hutan. Hutan mempunyai kedudukan dan peranan yang sangat penting dalam menunjang pembangunan nasional. Hutan sebagai modal pembangunan nasional memiliki manfaat yang nyata bagi kehidupan dan penghidupan bangsa Indonesia, baik manfaat ekologi, sosial budaya maupun ekonomi secara seimbang dan dinamis. Untuk itu hutan harus diurus, dikelola, dilindungi dan dimanfaatkan secara berkesinambungan bagi kesejahteraan $\mathrm{m}$ asyarakat Indonesia (Direktorat Jendral Planologi Kehutanan, 2014).

Hutan sebagai sumberdaya alam yang memberikan manfaat besar bagi kesejahteraan manusia,baik manfaat tangible yang dirasakan secara langsung, maupun intangible yang dirasakan secara tidak langsung. Manfaat hutan tersebut diperoleh apabila hutan terjamin eksistensinya sehingga dapat berfungsi secara optimal. Namun berbagai manfaat ini dapat dirasakan apabila hutan di kelola dengan benar. Saat ini berbagai manfaat yang dihasilkan hutan masih dinilai secara rendah sehingga menimbulkan terjadinya eksploitasi sumberdaya hutan yang berlebih. Hal tersebut disebabkan karena masih banyak pihak yang belum memahami nilai dari berbagai manfaat sumberdaya hutan secara komperehensif. Untuk memahami manfaat dari sumberdaya hutan tersebut perlu dilakukan penilaian terhadap semua manfaat yang dihasilkan sumberdaya hutan. Salah satu sumberdaya alam yang memberikan manfaat besar bagi kesejahteraan manusia khususnya di wilayah perkotaan adalah hutan kota.

Hutan kota sangat penting dalam pembangunan wilayah perkotaan. Pembangunan wilayah perkotaan yang terus meningkat secara ekonomi sangat baik namun secara ekologi menurun. Dengan keadaan wilayah perkotaan tersebut dirasa sangat penting adanya hutan di dalam wilayah perkotaan. Salah satu hutan kota di Makassar adalah Hutan Kota Kampus Universitas Hasanuddin (UNHAS) Tamalanrea dengan luas +20 ha 
sesuai Surat Keputusan Walikota Makassar No: 522.4/807/Kep/XI/2008 (Tambaru, 2012). Hutan kota sering dianggap bernilai ekonomi rendah sehingga cenderung diabaikan dan dialihfungsikan. Kondisi tersebut menyebabkan pembangunan dan pemeliharaan hutan kota tidak menjadi prioritas, akibatnya kondisi hutan kota yang ada tidak berkembang sebagaimana yang diharapkan. Selain itu fungsi hutan kota tidak dapat berjalan secara optimal, salah satu masalah adalah banjir hampir setiap tahun, terkait kurangnya daerah resapan air dan masalah drainase. Berdasarkan uraian tersebut maka dilakukan penelitian tentang nilai manfaat tidak langsung dari Hutan Kota Universitas Hasanuddin Makassar. Tujuan penelitian ini adalah (1) mengidentifikasi sumber-sumber manfaat ekonomi tidak langsung Hutan Kota Unhas Makassar yang ada saat ini (2) mengetahui nilai manfaat ekonomi tidak langsung Hutan Kota Unhas Makassar.

\section{METODE PENELITIAN}

\subsection{Waktu dan Tempat}

Penelitian ini dilaksanakan pada bulan Maret sampai Agustus 2018. Lokasi penelitian ini dilaksanakan di Hutan Kota Universitas Hasanuddin Makassar.

\subsection{Teknik Pengambilan Data}

Data yang diperoleh langsung melalui pengukuran terhadap objek-objek penilaian yang ada di Hutan Kota Universitas Hasanuddin Makassar. Data berupa keadaan umum kawasan Hutan Kota Universitas Hasanuddin Makassar dan data-data penunjang lainnya yang dikumpulkan melalui kajian pustaka, laporan maupun instansi-instansi terkait.

\subsection{Analisis Data}

Penelitian ini menggunakan metode analisis data yaitu :

\section{a. Nilai Ekonomi Kayu}

Untuk menentukan nilai manfaat tersebut dihitung berdasarkan pendekatan harga pasar. Menurut Husch B dkk (2003) formula nilai manfaat hasil hutan kayu dapat dituliskan sebagai berikut:

$$
\mathrm{NK}=(\mathrm{VK} \times \mathrm{H})
$$

$$
\begin{aligned}
& \text { Keterangan : } \\
& \text { NK = Nilai Manfaat Kayu }(\mathrm{Rp} / \mathrm{m} 3) \\
& \mathrm{H}=\text { = Harga Pasar (Rp) } \\
& \text { VK }=\text { Volume Kayu (m3) }
\end{aligned}
$$

\section{b. Nilai Ekonomi Kesejukan}

Nilai Kesejukan didasarkan pada analisis biaya dan manfaat dengan metode biaya pengganti yaitu biaya yang harus dikorbankan untuk mengganti jasa lingkungan yang dirusak (Roslinda, 2002 dalam Yulief, 2007). Penentuan nilai kesejukan didasarkan pada analisis biaya dan manfaat dengan metode biaya ganti yaitu biaya yang harus dikorbankan untuk mengganti jasa lingkungan yang rusak untuk mendapatkan kesejukan dengan rumus:

$$
H K=\frac{B P}{L}
$$




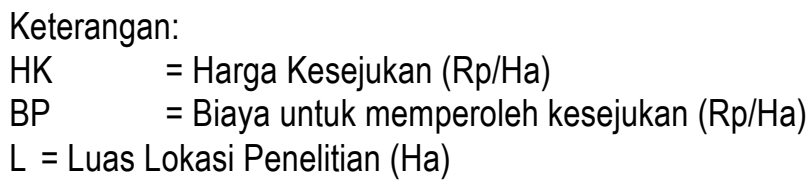

\section{c. Nilai Ekonomi Resapan Air}

Untuk mengetahui nilai resapan air diperoleh dari manfaat kawasan Hutan Kota Universitas Hasanuddin Makassar. Nilai resapan air dihitung berdasarkan pada kemampuan daya serap air oleh tanaman, dengan menggunakan asumsi bahwa satu pohon umur 10 tahun dapat menahan air kira-kira $7 \mathrm{~m}^{3}$ Nilai ekonomi resapan diperoleh dengan rumus

$$
\mathrm{Hsrp}=\mathrm{Tsa} \times \mathrm{Ha}
$$

$$
\begin{array}{ll}
\text { Keterangan : } \\
\text { Hsrp } & =\text { harga serapan air oleh pohon }\left(\mathrm{Rp} / \mathrm{m}^{3}\right) \\
\mathrm{Tsa} & =\text { Jumlah serapan air pepohonan }\left(\mathrm{m}^{3}\right) \\
\mathrm{Ha} & =\text { Harga Air PDAM Kota Makassar }\left(\mathrm{Rp} / \mathrm{m}^{3}\right)
\end{array}
$$

\section{HASIL DAN PEMBAHASAN}

\subsection{Sumber-sumber Manfaat Ekonomi Hutan Kota Makassar}

Hutan kota adalah ruang terbuka yang ditumbuhi vegetasi berkayu di wilayah perkotaan. Hutan kota memberikan manfaat lingkungan sebesar-besarnya kepada penduduk perkotaan, dalam kegunaan-kegunaan proteksi, estetika, rekreasi dan kegunaan khusus lainnya. Hutan kota merupakan bentuk persekutuan vegetasi pohon yang mampu menciptakan iklim mikro dan lokasinya di perkotaan atau dekat kota. Hutan di perkotaan ini tidak memungkinkan berada dalam areal yang luas. Bentuknya juga tidak harus dalam bentuk blok, akan tetapi hutan kota dapat dibangun pada berbagai penggunaan lahan. Oleh karena itu diperlukan kriteria untuk menetapkan bentuk dan luasan hutan kota. Kriteria penting yang dapat dipergunakan adalah kriteria lingkungan. Salah satu hutan kota di Makassar adalah Hutan Kota Kampus Universitas Hasanuddin (UNHAS). Hutan Kota merupakan ruang terbuka hijau yang didominasi oleh pohon dengan luas minimal 0,25 Ha. Persentase luas Hutan Kota paling sedikit $10 \%$ dari wilayah perkotaan. Luas Hutan Kota Kampus UNHAS Tamalanrea +20 ha dengan luas danau sebesar 6,48 Ha terdiri dari danau besar seluas $5 \mathrm{Ha}$, danau kecil $1,16 \mathrm{Ha}$ dan danau yang terletak di pinggir jalan raya $0,68 \mathrm{Ha}$.

Hutan kota sebagai salah satu ruang terbuka hijau kota sering dianggap bernilai ekonomi rendah sehingga cenderung diabaikan dan dialihfungsikan. Hutan kota Universitas Hasanuddin memiliki nilai manfaat yang sangat besar dan memiliki nilai manfaat yang tinggi. Beberapa nilai manfaat ekonomi yang terdapat di Hutan Kota yaitu nilai manfaat kayu, nilai manfaat kesejukan dan manfaat resapan air. Hutan kota bermanfaat untuk mengurangi degradasi lingkungan kota yang diakibatkan oleh pembangunan. Selain mempunyai fungsi perbaikan lingkungan hidup, hutan kota juga memiliki nilai estetika. Semakin banyaknya bangunan, keberadaan ruang terbuka hijau menjadi terbatas. Sehingga berpengaruh pada ketidakseimbangan ekosistem, seperti rusaknya fungsi resapan air dan lain-lain. 


\subsection{Nilai Manfaat Ekonomi Kayu}

Nilai kayu merupakan salah satu nilai manfaat langsung yang diperoleh karena adanya hutan Kota Universitas Hasanuddin. Sebatang pohon yang tumbuh di hutan kota mempunyai nilai ekonomi yang besar yang berasal dari nilai kayu tersebut. Untuk menghitung nilai manfaat kayu yang terdapat di lokasi penelitian menggunakan pendekatan harga pasar. Pendekatan harga pasar merupakan pendugaan manfaat dari kegiatan produksi dan konsumsi dalam kehidupan sehari-hari. Barang dan jasa yang dihasilkan hutan dan diperdagangkan (memiliki harga pasar) diantaranya adalah hasil hutan kayu, produk hasil hutan non kayu seperti pangan, tumbuhan obat, hidupan liar dan rekreasi. Untuk produk-produk tersebut, harga pasar dapat digunakan untuk menggambarkan perhitungan finansial, untuk membandingkan antara manfaat dan biaya dari berbagai alternatif pilihan penggunaan lahan hutan. Harga pasar diturunkan melalui interaksi antara produsen dan konsumen melalui permintaan dan penyediaan barang dan jasa (transaksi pasar).

Hutan Kota UNHAS memiliki potensi kayu yang sangat besar.Nilai kayu merupakan nilai ekonomi yang dimiliki oleh hutan kota yang belum dihitung oleh pemerintah setempat namun pada dasarnya pemerintah sudah menyadari nilai manfaat ekonomi yang terdapat dalam hutan kota khususnya nilai manfaat kayunya. Hal ini dapat terlihat dari program penghijauan yang dilaksanakan. Namun kegiatan tersebut belum direncanakan dengan matang. Hal ini dapat terlihat apabila aparat memangkas pohon tanpa memperhatikan bentuk tajuk dan pohon yang sudah ditanam pun juga ikut ditebang. Hal ini membuktikan bahwa pemerintah belum memahami nilai yang diberikan dari sebatang pohon untuk kehidupan manusia. Nilai manfaat ekonomi kayu Hutan Kota Unhas dapat dilihat pada Tabel 1.

Tabel 1. Nilai Manfaat Ekonomi Kayu Hutan Kota UNHAS

\begin{tabular}{ccr}
\hline PLOT & Total volume plot $(\mathrm{m} 3)$ & Nilai Kayu $(\mathrm{Rp} / \mathrm{m} 3)$ \\
\hline 1 & 1,96 & 685.280 \\
2 & 3,21 & 1.123 .406 \\
3 & 4,59 & $1.607 .017,49$ \\
4 & 2,59 & $906.773,6$ \\
5 & 1,43 & $3.565 .21,53$ \\
6 & 1,77 & $442.814,60$ \\
\hline TOTAL & $\mathbf{1 5 , 5 5}$ & $\mathbf{5 . 1 2 1 . 8 1 3 , 2 2}$ \\
\hline
\end{tabular}

Berdasarkan Tabel 1 diketahui bahwa masing-masing plot memiliki nilai manfaat kayu yang berbedabeda. Hal ini disebabkan karena volume pohonnya pun berbeda-beda. Untuk plot 1 nilai manfaat kayu sebesar Rp. $685.280 / \mathrm{m}^{3}$, plot 2 nilai manfaat kayu sebesar Rp. $1.123 .406 / \mathrm{m}^{3}$, plot 3 nilai manfaat kayu sebesar Rp. $1.607 .017,49 / \mathrm{m} 3$, plot 4 nilai manfaat kayu sebesar Rp. $906.773,6 / \mathrm{m}^{3}$, plot 5 nilai manfaat kayu sebesar Rp. $3.565 .21,53 / \mathrm{m}^{3}$ dan plot 6 sebesar Rp. 442.814,60. Sehingga total nilai manfaat ekonomi kayu untuk semua plot sebesar Rp. $5.121 .813,22 / \mathrm{m}^{3}$. Nilai kayu diperoleh dari hasil perkalian antara volume pohon dengan harga kayu di pasaran berdasarkan jenis kayu yang terdapat dilokasi penelitian.

Hasil potensi nilai manfaat ekonomi kayu yang ada di Hutan Kota Unhas diperkirakan rata-rata adalah $11,8 \mathrm{~m} 3 / \mathrm{Ha}$. Luas hutan kota yang digunakan dalam perhitungan ini adalah daerah yang ditanami pepohonan yang diperoleh dari pengurangan luas total hutan kota Unhas dengan luas danau yaitu 13,16 Ha. Harga kayu tegakan sebesar Rp.300.000/m³. Sehingga diperoleh nilai kayu hutan kota Unhas adalah Rp. 3.540.000/Ha/tahun. Untuk nilai total nilai manfaat kayu adalah Rp 46.586.400/Tahun. Pada penelitian lain yang dilakukan oleh Nur Raly Anjani bahwa nilai ekonomi pohon di Hutan Kota Tebet dihitung dengan konsep harga pasar yaitu perkalian jumlah komoditas dengan harga komoditas. Hasil inventarisasi jumlah pohon yang dilakukan Dinas Pertamanan dan Pemakaman DKI Jakarta tahun 2013 terdapat 1670 pohon kayu dan 33 
学

Jurnal Hutan dan Masyarakat. Vol. 10(2): 239-245, Desember 2018

Diserahkan: 2018-08-11; Diterima: 2018-12-27

ISSN: 1907-5316 ISSN ONLINE: 2613-9979

pohon palem. Penentuan harga palem dengan survey penjual, dimana pohon palem dengan tinggi $2 \mathrm{~m}$ dipatok dengan harga Rp. 7.000.000,--

Nilai kayu merupakan nilai produktifitas yang dimiliki oleh hutan kota yang belum pernah dihitung oleh pemerintah Kota Makassar. Dilihat dari pepohononnya, hutan kota UNHAS terdiri dari pepohonan yang membentuk tajuk tinggi dan rumput-rumput penutup tanah. Dengan adanya pepohonan yang membentuk tajuk tinggi tersebut maka hutan kota UNHAS menjadi salah satu aset penting bagi Pemerintah Kota Makassar yang akan terus berkembang. Namun hal ini tidak disadari oleh Pemerinah Kota Makassar dan msyarakat setempat. Oleh karena itu sangat diharapkan hutan kota ini dapat memberikan informasi terhadap manfaat hutan kota sehingga dapat memotivasi dan meningkatkan kepedulian masyarakat tentang lingkungan.

\subsection{Nilai Manfaat Ekonomi Kesejukan}

Hutan kota merupakan salah satu komponen ruang terbuka hijau yang keberadaannya sangat penting dalam kehidupan. Keberadaan hutan kota sangat penting karena memiliki banyak fungsi. Fungsi hutan kota sebagai system hidrologi, menciptakan iklim mikro, menjaga keseimbangan oksigen dan karbon dioksida, mengurangi polutan dan menciptakan kesejukan. Hutan kota yang ditumbuhi berbagai tanaman, memberikan nilai keindahan karena hijaunya hutan dengan aneka bentuk macam daun, ranting dan bunga yang menjadikan suatu pemandangan yang menyejukkan serta menambah keasrian kota. Seperti yang terdapat dalam Hutan Kota UNHAS. Dengan rimbunnya dedaunan pohon menambah kesejukan bagi pengunjung. Ditambah lagi danau sehingga masyarakat dapat menemukan sedikit ketenangan. Dengan rimbunnya pohon maka suhu udara pada hutan kota lebih nyaman dibandingkan dengan daerah diluar hutan kota. Ekosistem di bawah pepohonan lebih rendah suhunya 3-5 dan kelembaban di dalam ekosistem hutan lebih tinggi 20-30\%. Dari penelitian tersebut diketahui bahwa dengan adanya hutan kota dapat menciptakan lingkungan kota yang sejuk dan nyaman.

Penentuan nilai ekonomi kesejukan diperoleh dengan menggunakan teknik analisis biaya, yaitu pendekatan dengan menilai manfaat ekonomi yang hilang akibat kerusakan lingkungan dengan mengukur biaya mengganti jasa lingkungan yang dirusak orang. Nilai ekonomi kesejukan dihitung dari total biaya pengadaan AC dan biaya perawatannya. Pemakaian AC diasumsikan sebagai pengganti pohon yang dilakukan sebagai pengganti untuk memperoleh kesejukan udara.

Hasil penelitian yang dilakukan oleh Juita S (2016) bahwa pendekatan untuk mendapatkan nilai kesejukan adalah pendekatan harga pengganti, yaitu dalam hal ini menggunakan pendekatan biaya pengadaan AC untuk mendapatkan nilai kesejukan Harga AC 5 PK sebesar Rp 10.000.000. nilai kesejukan di jogging track dan Arboretum berbeda disebabkan oleh luasan kawasan yang berbeda, yaitu luas kawasan Arboretum sebesar 3,2 Ha dengan nilai kesejukan Rp 3.200.000.000,- dan kawasan jogging track hanya $3 \mathrm{Ha}$ dengan nilai kesejukan $\mathrm{Rp} 3.000 .000 .000$,-. Sehingga diperoleh nilai total kesejukan sebesar $\mathrm{Rp}$ 6.200.000.000.

Sama halnya dengan perhitungan Hutan Kota Kawasan Universitas Tanjungpura Pontianak, untuk menghitung nilai manfaat kesejukan Hutan Kota Unhas juga menggunakan analisis biaya pengganti dengan menggunakan AC. AC merupakan alat pengatur suhu ruangan yang dapat kita peroleh di toko elektronik dengan biaya yang cukup mahal. Tidak sedikit biaya yang dikeluarkan untuk pengadaan AC serta biaya perawatannya. AC memiliki kemampuan yang terbatas untuk menurunkan suhu suatu ruangan. 1 (satu) unit AC 1 pk diperkirakan mampu mendinginkan ruangan $4 \times 5 \mathrm{~m}$. Sehingga untuk luasan $20 \mathrm{Ha}$ dibutuhkan 10.000 unit AC dengan harga Rp. 3.457.800/unit AC. Jadi pengadaan AC sebesar Rp. 34.578.000.000. Untuk biaya perawatan meliputi biaya pembersihan dan biaya pengisian Freon. Biaya perawatan sebesar Rp. 2.250.000.000. Sehingga diperoleh nilai kesejukan Hutan Kota Unhas sebesar Rp. 36.828.000.000. Kedua lokasi tersebut memiliki perbedaan dalam memperoleh nilai ekonomi kesejukan karena pada Hutan Kota Unhas menghitung nilai perawatan, pembersihan dan pengisian freon. 
Nilai kesejukan mempunyai nilai manfaat ekonomi yang tinggi yang diberikan oleh Hutan Kota UNHAS terhadap pengunjungnya. Dengan mengetahui nilai kesejukan ini diharapkan pemerintah Kota Makassar dapat lebih menghargai dan manjaga Hutan Kota.

\subsection{Nilai Manfaat Ekonomi Resapan Air}

Hutan sebagai suatu ekosistem tidak hanya menyimpan sumberdaya alam berupa kayu, tetapi masih banyak potensi non kayu yang dapat diambil manfaatnya oleh masyarakat melalui budidaya tanaman pertanian pada lahan hutan. Sebagai fungsi ekosistem hutan sangat berperan dalam berbagai hal seperti penyedia sumber air, penghasil oksigen, tempat hidup berjuta flora dan fauna, dan peran penyeimbang lingkungan, serta mencegah timbulnya pemanasan global. Sebagai fungsi penyedia air bagi kehidupan hutan merupakan salah satu kawasan yang sangat penting, hal ini dikarenakan hutan adalah tempat bertumbuhnya berjuta tanaman. Sistem perakaran tanaman dan serasah yang berubah menjadi humus akan memperbesar jumlah pori tanah. Karena humus bersifat lebih higroskopis dengan kemampuan menyerap air yang besar maka kadar air tanah hutan akan meningkat. Jika hujan lebat terjadi, maka air hujan akan turun masuk meresap ke lapisan tanah yang lebih dalam menjadi air infiltrasi dan air tanah dan hanya sedikit yang menjadi air limpasan. Dengan demikian pelestarian hutan pada daerah resapan air dari kota yang bersangkutan akan dapat membantu mengatasi masalah air dengan kualitas yang baik.

Hutan memiliki kemampuan sebagai regulator air, artinya ia mampu mengatur, menyokong proses alami dan menyediakan air bersih apabila ia dibiarkan tetap alami. la mampu menyimpan air di musim hujan dimana ketersediaan air berlimpah, ia juga mampu melepaskan air saat musim kemarau, saat dimana ketersediaan air sangat kurang. Hutan menjadi satu hal yang sangat vital terhadap persediaan atau pasokan air bersih bagi manusia. la mampu menyaring dan membersihkan air lebih baik dan lebih murah daripada sistem yang diciptakan oleh manusia.

Hutan kota memiliki infiltrasi yang tinggi, karena memiliki sistem perakaran dan serasah yang berubah menjadi humus sehingga dapat memperbesar pori tanah. Karena humus memiliki kemampuan menyerap air yang besar, maka kadar air dalam hutan pasti akan meningkat. Nilai ekonomi resapan air hutan kota Unhas dihitung berdasarkan kemampuan pohon untuk dapat menahan air. Menurut Sjarief (2006) diasumsikan bahwa satu pohon berusia 10 tahun dapat menahan air kira-kira $7 \mathrm{~m} 3$ setara dengan $5 \mathrm{~m} 3$ per hektar. Sehingga diperoleh kemampuan pepohonan hutan kota untuk menahan air sebesar 16,52 m3 atau 113 $\mathrm{m} 3 / \mathrm{Ha}$.

Nilai ekonomi resapan air hutan kota Unhas diperoleh dari besarnya biaya yang dikeluarkan oleh penduduk untuk membayar air PDAM yaitu Rp. 3.400 m3/detik. Nilai manfaat ekonomi resapan nilai air hutan kota Unhas adalah Rp. 384.189,12/hari sehingga nilai resapan air hutan kota Unhas selama setahun adalah Rp. 140.229.028,8/tahun. Sebuah survey di Amerika Serikat menunjukkan bahwa biaya pengolahan air dalam area dimana daerah aliran sungai (DAS) masih memiliki tutupan hutan sebanyak $60 \%$, adalah setengah dari biaya pengolahan air di area dengan tutupan hutan hanya 30\%. Diperkirakan bahwa setiap US\$1 yang dihabiskan untuk perlindungan hutan dan DAS akan menghemat biaya pengolahan air sebanyak US\$7,50 hingga US\$200.

Nilai resapan air merupakan kemampuan sebuah hutan untuk mempertahankan air tanah yang dibutuhkan dalam kehidupan manusia. Demikian halnya dengan hutan kota Unhas. Pembangunan hutan kota memberikan dampak positif bagi masyarakat yaitu dapat meningkatkan ketersediaan air tanah bagi kehidupan. Dengan menyelamatkan daerah resapan air maka dapat menyelamatkan kehidupan manusia.

\section{KESIMPULAN}

Berdasarkan hasil penelitian maka dapat dapat ditarik kesimpulan yaitu milai manfaat ekonomi Hutan Kota Makassar yaitu Nilai kayu, nilai kesejukan, nilai resapan air. Nilai manfaat ekonomi yang terdapat di Hutan Kota yaitu nilai kayu hutan kota Unhas adalah Rp. 46.586.400/Tahun. Nilai kesejukan Hutan Kota 
Unhas sebesar Rp. 3.6828.000.000. Nilai manfaat ekonomi resapan nilai air hutan kota Unhas adalah Rp. 384.189,12/hari sehingga nilai resapan air hutan kota Unhas selama setahun adalah Rp. 140.229.028,8/tahun.

\section{DAFTAR PUSTAKA}

Affandi, O., Zaitunah, A., \& Batubara, R. (2017). Potential Economic and Development Prospects of Non Timber Forest Products in Community Agroforestry Land around Sibolangit Tourism Park. Forest and Society, 1(1), 68-77. doi:http://dx.doi.org/10.24259/fs.v1i1.1096

Anjani, N. R., \& Harini, R. (2016). Valuasi Ekonomi Hutan Kota Tebet Jakarta Selatan di DKI Jakarta. Jurnal Bumi Indonesia, 5(1).

Bambang, 1995. Hutan dan Pembangunan Bidang Kehutanan. PT. Gramedia. Jakarta.

Budihardjo dan Hardjohubojo, 1993.Tata Ruang dan Pola Perkembangan Kota Indonesia.Perencanaan Wilayah Kota.Bandung : Institut Teknologi Bandung.

Dahlan E N. 2004. Membangun Kota kebun (Garden City) Bernuansa Hutan kota. IPB Press. Bogor.

Ditjen Planologi Kehutanan. 2014. Potensi Sumber Daya Hutan Dari Plot Inventarisasi Hutan Nasional. Direktorat Inventarisasi dan Pemantauan Sumber Daya Hutan. Jakarta.

Fauzi, A., 2004. Ekonomi Sumberdaya Alam dan Lingkungan : Teori dan Aplikasi. Gramedia. Jakarta.

Fisher, M., Maryudi, A., \& Sahide, M. (2017). Forest and Society: Initiating a Southeast Asia Journal for Theoretical, Empirical, and Regional Scholarship. Forest and Society, 1(1), 1-7. doi:http://dx.doi.org/10.24259/fs.v1i1.1369

Harini, R., Yunus, H. S., Kasto, K., \& Hartono, S. (2013). Nilai Ekonomi Total Konversi Lahan Pertanian Di Kabupaten Sleman (Total Economic Value of the Land Agricultural Conversion in Sleman Regency). Jurnal Manusia dan Lingkungan, 20(1), 35-48.

Husch B, Beers TW and Kershaw JA. 2003. Forest Mensuration, Fourth Edition. John Wiley \& Sons, Inc.

Juita, S., Lumangkun, A., \& Dewantara, I. Penilaian Ekonomi Jasa Lingkungan Hutan Kota Pada Kawasan Universitas Tanjungpura Pontianak. Jurnal Hutan Lestari, Vol 4 No 3: 380-386.

Muthmainnah, M., \& Sribianti, I. (2017). Nilai Manfaat Ekonomi Tanaman Nipah (Nypa Fruticans) Desa Lakkang Kecamatan Tallo Kota Makassar. Jurnal Hutan Tropis, 4(2), 140-144.

Pemerintah Republik Indonesia. 2002. Peraturan Pemerintah Republik Indonesia Nomor 63 Tahun 2002 tentang Hutan kota. Republik Indonesia.

Peraturan Pemerintah Republik Indonesia. 2008. Nomor : 26, Tentang RencanaTata Ruang Wilayah Nasional. Sekretariat Negara RepublikIndonesia. Jakarta.

Subarudi, S., \& Samsoedin, I. (2012). Kajian Kebijakan Hutan Kota: Studi Kasus di Provinsi Daerah Khusus Ibu Kota Jakarta (DKI). Jurnal Analisis Kebijakan Kehutanan Volume 9 No 2 Agustus 2012:144-153.

Tambaru, E., 2012. Potensi Absorpsi Karbon Dioksida Pada Beberapa Jenis Pohon Hutan Kota di Kota Makassar, Pasca Sarjana Universitas Hasanuddin, Makassar.

Yulief, EM. 2007. Penilaian Ekonomi Hutan Kota (Studi Kasus : Hutan Kota Srenseng, Jakarta Barat). Program Pasca Sarjana. Universi tas Indonesia.

Zain, A.S, 1998. Aspek Pembinaan Kawasan Hutan Dan Stratifikasi Hutan Rakyat. Rineka Cipta, Jakarta. 